\title{
Uma proposta de aula experimental no ensino a distância: Identificando proteínas em alimentos do cotidiano na disciplina de Bioquímica
}

An experimental class proposal in distance learning: Identifying proteins in everyday foods in the discipline of Biochemistry

Una propuesta de clase experimental en educación a distancia: Identificación de proteínas en alimentos cotidianos en la disciplina de Bioquímica

\section{Resumo}

$\mathrm{Na}$ atualidade, a Educação a Distância (EaD) têm sido cada vez mais difundida, sendo um importante meio de ensino. No ano de 2020, com o advento da pandemia do novo coronavírus, o ensino tem se pautado no modo a distância, principalmente em plataformas virtuais de ensino (vídeoaulas). A Bioquímica é uma área fascinante, no entanto, possui diversos termos e processos que devem ser muito bem assimilados e compreendidos, tornando essa disciplina complexa e desafiadora aos alunos. Assim, para superarmos tais obstáculos o objetivo deste trabalho é a proposta de uma aula experimental virtual com a temática de identificação das proteínas em diversos alimentos do cotidiano, utilizando o reagente de Biureto, aplicado aos alunos de cursos superiores voltados nas áreas de Ciências Biológicas e cursos voltados nas áreas da Saúde. Desse modo, acreditamos que com presente proposta metodológica, as aulas virtuais possam se tornar cada vez mais cativantes, motivando o aluno e facilitando sua aprendizagem, além de promover a ótica da experimentação científica.

Palavras-chave: Educação a distância; Bioquímica; Proteínas; Teste de Biureto; Laboratório; Ensino.

\begin{abstract}
Currently, Distance Education (EaD) has been increasingly widespread, being an important means of teaching. In 2020, with the advent of the new coronavirus pandemic, teaching has been based on distance learning, mainly on virtual teaching platforms (video lessons). Biochemistry is a fascinating area, however, it has several terms and processes that must be very well assimilated and understood, making this discipline complex and challenging to students. Thus, in order to overcome such obstacles, the objective of this work is the proposal of a virtual experimental class with the theme of identification of proteins in different foods of everyday life, using the Biuret reagent, applied to students of higher education courses focused on Biological Sciences courses focused on Health areas. Thus, we believe that with this methodological proposal, virtual classes can become increasingly captivating, motivating students and facilitating their learning, in addition to promoting the perspective of scientific experimentation.
\end{abstract}

Keywords: Distance education; Biochemistry; Proteins; Biuret test; Laboratory; Teach.

\section{Resumen}

En la actualidad, la Educación a Distancia $(\mathrm{EaD})$ está cada vez más extendida, siendo un importante medio de enseñanza. En 2020, con la llegada de la nueva pandemia de coronavirus, la enseñanza se ha basado en el aprendizaje a distancia, principalmente en plataformas de enseñanza virtual (videoclases). La bioquímica es un área fascinante, sin embargo, tiene varios términos y procesos que deben asimilarse y entenderse muy bien, lo que hace que esta disciplina sea compleja y desafiante para los estudiantes. Así, para superar tales obstáculos, el objetivo de este trabajo es la propuesta de una clase experimental virtual con el tema de identificación de proteínas en diferentes alimentos de la vida cotidiana, utilizando el reactivo de Biuret, aplicado a estudiantes de cursos de educación superior enfocados a las áreas de Ciencias Biológicas y cursos enfocados a las áreas de la Salud, por lo que creemos que con esta propuesta metodológica, las clases virtuales pueden volverse cada vez más cautivadoras, motivando a los estudiantes y facilitando su aprendizaje, además de promover la perspectiva de la experimentación científica.

Palabras clave: Educación a distancia; Bioquímica; Proteínas prueba de Biuret; Laboratorio; Ensenãnza. 


\section{Introdução}

No mundo, segundo Marques (2004), o Ensino a Distância (EaD) surgiu por volta de 1850 com o intuito de agricultores e pecuaristas europeus aprenderem por meio de correspondências qual a melhor forma de plantar e cuidar dos seus rebanhos. Já, no Brasil, esse mesmo autor, relata que o ensino EaD surgiu no século passado no ano de 1939, no Instituto Monitor e logo em seguida com o Instituto Universal Brasileiro, em ambos o método de ensino era semelhante por meio de correspondências. Segundo Costa e Faria (2008), em 1995, surgiu no país o CEAD (Centro Nacional de Educação a Distância). A década de 90 propiciou ainda a criação da Universidade Aberta de Brasília que possibilitou o desenvolvimento três campos diferenciados tais como: conhecimento cultural: que consistia na organização de cursos específicos de acesso a todos; Educação continuada: reciclagem profissional às diversas categorias de trabalhadores e àqueles que já passaram pela universidade; Ensino superior: englobando tanto a graduação como a pós-graduação.

Hoje, no Brasil, o ensino da modalidade EaD se desponta como sendo de grande importância, uma vez que vêm para democratizar a disseminação da educação em todos os locais do nosso país. Dados recentes do INEP (Instituto Nacional de Estudos e Pesquisas Educacionais Anísio Teixeira) demonstraram que no ensino EaD no ano de 2019, ingressaram mais de 1 milhão de 500 mil alunos na Universidade, tanto no ensino público quanto privado, ressaltando assim seu avanço e popularização. (Inep, 2019). Assim, como destaca Lacerda e Espíndola (2013), o ensino EaD sendo bem utilizado pode trazer benefícios para o nosso país, uma vez que este possui um grande território que apresentam deficiências educativas. Dessa maneira, os autores relatam que os benefícios advindos do ensino na modalidade EaD levar cursos superiores para áreas afastadas dos grandes centros, popularizando a educação. Outro benefício destacado por Neder (2006), é que a EaD permite formar um maior número de profissionais em detrimento ao seu fácil acesso, com sua composição bastante heterogênea trazendo novas idéias de atuação profissional e educacional.

No que tange a Bioquímica, os autores Voet e Prat (2008) a define como a área da Biologia que estuda a química da vida. Assim, Nelson e Cox (2008) ressaltam que essa área se preocupa em descrever os aspectos moleculares das estruturas químicas, os mecanismos e os processos químicos compartilhados por todos os seres vivos fornecendo princípios de organização que estão subjacentes à vida e em todas suas diversas formas.

No ensino superior em cursos ligados as áreas de Biológicas, a Bioquímica possui uma grande quantidade de termos e processos que devem ser muito bem assimilados e compreendidos pelos alunos, tornando essa disciplina muito complexa e desafiadora. Assim, na literatura diversos autores relatam a utilização de aulas práticas com o intuito de facilitar o processo norteador da aprendizagem, tornando o assunto mais cativante e prazeroso aos discentes. Em relação a isso, Interaminense (2019) ressalta que, as aulas práticas são metodologias de ensino importantes de pesquisa, uma vez que promove ao aluno experimentar situações problematizadas e vivenciar a teoria de conceitos em sala de aula. Já, Gonçalves (2021a; 2021b) afirmam que, as aulas práticas podem permitir a aplicação dos conceitos vivenciados nas aulas teóricas, facilitando a aprendizagem do tema proposto, além de promover a discussão e a proposição de hipóteses, despertando a ótica de experimentação científica dos discentes.

Neste sentido, segundo Trivelato e Silva (2011, p. 76),

o professor assume um papel fundamental nesse processo investigativo, no sentido de propor problemas, acompanhar as discussões, promover novas oportunidades de reflexão, estimular, desafiar, argumentar, ou seja, tornar-se um orientador da aprendizagem de seus alunos e auxilia a passagem do senso comum para o saber científico. (Trivelato e Silva, 2011, p.76).

Assim, a função do professor é a de promover a construção dos discentes a passagem do saber cotidiano para o saber científico, por meio da atividade investigativa (experimentação) e dos próprios questionamentos relacionados ao fenômeno que 
está sendo trabalhado. (Azevedo, 2004).

Nos tempos atuais em detrimento do novo coronavírus, as aulas no ensino superior estão sendo ministradas na modalidade EaD (virtual), assim, para superarmos todos os obstáculos tornando o ensino mais cativante e facilitando a aprendizagem da Bioquímica, propomos neste trabalho a abordagem de uma aula prática experimental, com o intuito de identificar a presença de proteínas em alimentos do cotidiano por meio do teste de Biureto. Nessa atividade, será possível ao professor discutir e problematizar situações e conceitos relacionados à grande esfera da Bioquímica (proteínas) voltada aos alunos do ensino superior em cursos de Ciências Biológicas e da Saúde. Além da Bioquímica, essa atividade pode servir como eixo integrador entre outras áreas da Biologia, permitindo ao docente trabalhar aspectos relacionados a nutrição, dieta e até mesmo a área da Botânica. No Quadro 1, está disposto de maneira sucinta as competências e suas descrições que o docente pode abordar aos alunos com a realização da presente atividade prática.

Quadro 1. Objetivo, conteúdo e habilidades trabalhados na atividade proposta.

\begin{tabular}{|c|l|}
\hline Competências & \multicolumn{1}{|c|}{ Descrição } \\
\hline Objetivo da atividade prática & $\begin{array}{l}\text { Identificar as proteínas presentes nos alimentos, bem como } \\
\text { facilitar a compreensão da estrutura das proteínas e sua } \\
\text { importância na manutenção da vida }\end{array}$ \\
\hline Conteúdo abordado & $\begin{array}{l}\text { Bioquímica (Proteínas), além de outros assuntos como } \\
\text { nutrição e dieta. }\end{array}$ \\
\hline Habilidades & $\begin{array}{l}\text { Desenvolver no aluno a prática de atividades experimentais } \\
\text { científicas, além de formular hipóteses e explicar os } \\
\text { resultados obtidos. }\end{array}$ \\
\hline
\end{tabular}

Fonte: Autores (2021).

\section{Metodologia Experimental}

A atividade proposta possui caráter qualitativo com uma abordagem didático-experimental possuindo base metodológica proposta por Pereira et al. (2018).

\subsection{Materiais necessários para a condução da atividade}

Para a condução da atividade serão necessários os seguintes materiais:

- $\quad \mathrm{NaOH}$ (Hidróxido de Sódio - facilmente adquirido no supermercado na forma granular ou em pó);

- $\quad \mathrm{CuSO} 4$ a 5\% (Sulfato de cobre - adquirido em lojas de produtos agrícolas e agropecuários);

- 2 Copos com graduações;

- 1 pote com $200 \mathrm{ml}$ para armazenamento do reativo de Biureto;

- 11 copinhos de café de $50 \mathrm{ml}$ para acondicionamento dos alimentos a serem testados;

- $\quad$ Seringas de plástico de $5 \mathrm{ml}$ (adquirida em farmácias);

- $\quad$ Colher de chá,

- $\quad$ Colher de sopa;

- Caneta marcador ou retroprojetor para identificação dos copinhos;

- $\quad$ Leite integral; 
- $\quad$ Amido de milho (Maisena);

- Clara do ovo;

- $\quad$ Gema do ovo;

- $\quad$ Carne moída de frango ou boi;

- Whey protein em pó;

- $\quad$ Extrato de Ervilhas em pó (facilmente adquirido em casas de produtos naturais);

- $\quad$ Colágeno hidrolisado em pó (adquirido em casas de produtos naturais);

- Castanha-do-pará;

- $\quad$ Pedacinhos de pão francês (também pode ser pão de forma, ou caseiro).

- $\quad$ Ralador de cozinha;

- Luvas;

- Jaleco;

- $\quad$ Óculos de segurança.

- $\quad$ Lista de exercícios a ser entregue aos alunos (Tópico 5)

- $\quad$ Respostas esperadas das questões (Tópico 6).

Na Figura 1, estão exibidos os alimentos propostos utilizados nessa aula prática. Vale a pena ressaltarmos que fica a critério do professor a escolha e utilização de outros alimentos, uma vez que pode ser incluído alimentos regionais por exemplo, tornando a aula prática mais inclusiva e integradora. No tópico 5, é sugerido um banco de questões para potencializar a aprendizagem dos alunos, acerca da aula experimental proposta. No tópico 6, o professor pode acessar as respostas das questões.

Figura 1. Alimentos utilizados na aula prática.

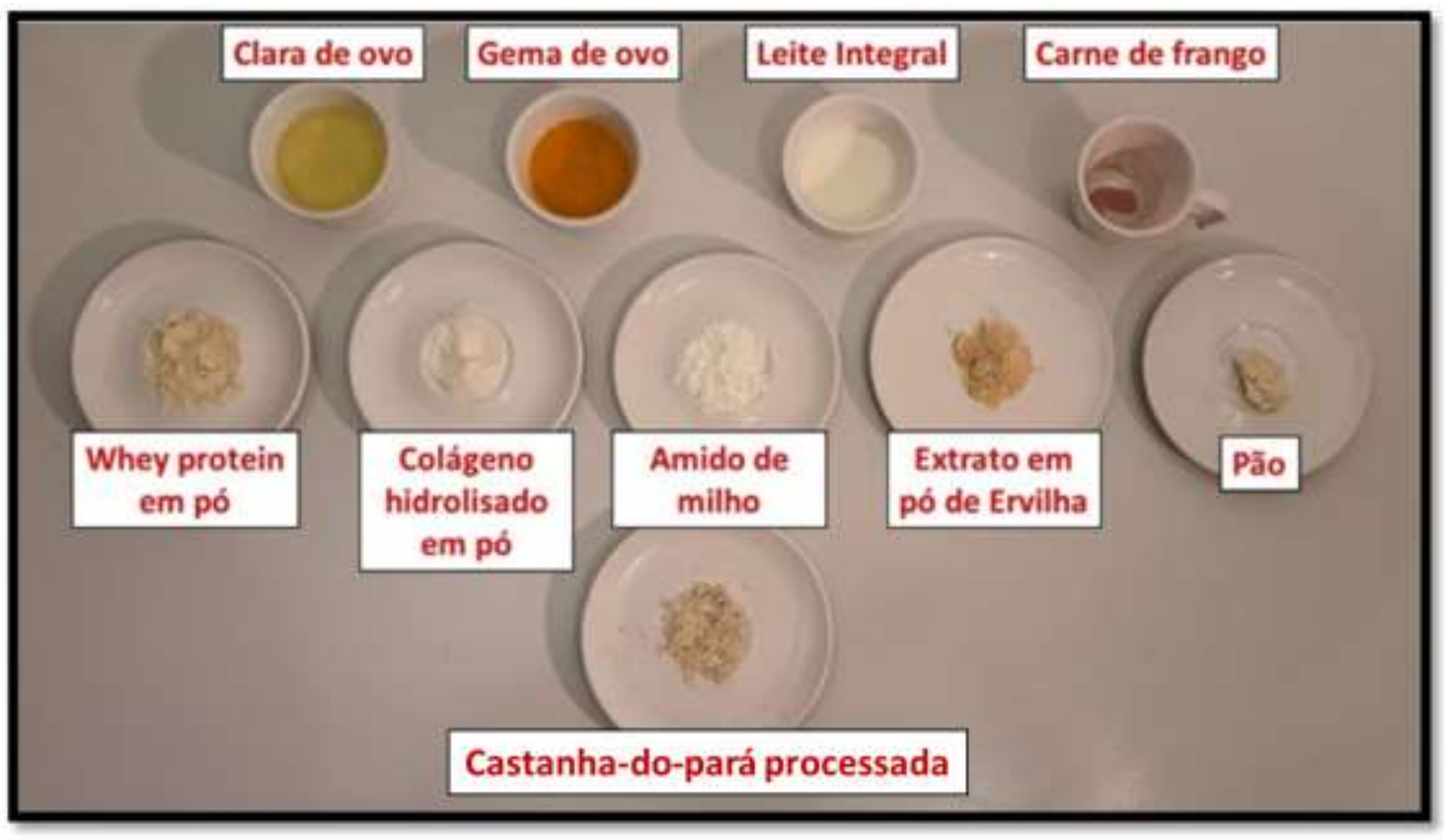

Fonte: Autores (2021). 


\subsection{Metodologia inicial: preparo do reagente de biureto}

Para preparar o reagente de Biureto que será utilizado na identificação das proteínas temos que seguir alguns cuidados. O professor deve chamar a atenção que na dissolução do $\mathrm{NaOH}$ em pó na água é uma reação exergônica, ou seja libera calor, podendo até mesmo queimar a mucosa. Assim, nessa etapa deve ser utilizado óculos de segurança, luvas além de um jaleco para proteger o corpo. Para preparo da solução de $\mathrm{NaOH}$, devemos inicialmente colocar 1 colher de sopa do reagente em aproximadamente $100 \mathrm{ml}$ de água, em um frasco de $200 \mathrm{ml}$. Mexer sempre no mesmo sentido com uma colher e tomar cuidado com a vaporização. A solução estará pronta quando estiver totalmente cristalina (translúcida). Após isso, colocar (50 $\mathrm{ml}$ ) de Sulfato de Cobre a 5\% (CuSO4), mexer a solução e armazenar. O reagente que irá identificar as proteínas dos alimentos está pronto, e ele é denominado de Reagente ou Reativo de Biureto.

\subsection{Identificando os copinhos com as amostras a serem testadas}

Enumerar os copinhos de café de $50 \mathrm{ml}$ com a caneta de retroprojetor ou marca texto de 1 a 11, conforme a sequência indicada no Quadro 2:

Quadro 1. Numeração dos copinhos e seus respectivos alimentos.

\begin{tabular}{|c|c|c|c|}
\hline Copo no & Alimento & Copo no $^{\mathbf{0}}$ & Alimento \\
\hline 1 & Leite Integral & 6 & Clara de ovo \\
\hline 2 & Carne moída (boi ou frango) & 7 & Gema de ovo \\
\hline 3 & Whey protein em pó & 8 & Castanha-do-pará processada \\
\hline 4 & Colágeno hidrolisado em pó & 9 & Amido de Milho \\
\hline 5 & Extrato de ervilhas em pó & 10 & Pão \\
\hline \multicolumn{2}{|c|}{ Copinho número 11 = controle da reação (água $\left.+\mathrm{NaOH}+\mathrm{CuSO}_{4}\right)$} \\
\hline
\end{tabular}

Fonte: Autores (2021).

\subsection{Preparando os alimentos a serem testados}

Em cada um dos copinhos, deverá ser colocado por meio da seringa, $2 \mathrm{ml}$ de água. Após isso, colocar em cada um deles uma pequena porção dos alimentos listados na ordem que segue no quadro 1. Para o leite, a clara e a gema colocar de 2 a 3 ml. Para os alimentos em pó colocar uma colher de chá. A castanha-do-pará deve ser ralada com o auxílio de um ralador, para obtenção de um pó. Vale a pena ressaltarmos que os alimentos sólidos (carne de frango ou de boi) deverão ser macerados utilizando-se uma colher. Essa tarefa é importante e o professor pode explicar aos alunos que ao macerar os alimentos sólidos a sua área de contato fica maior, possibilitando uma maior interação entre o reagente (Biureto) e as proteínas dos alimentos. Assim, nas Figuras 2, 3 e 4 estão evidenciados como estarão dispostos nos tubos de ensaio os alimentos a serem testados. $\mathrm{Na}$ Figura 4, observar no tubo de ensaio número 11 a coloração do reativo de Biureto (coloração original azul clara do controle). Aqui, foi utilizado para a condução do experimento tubos de ensaio, porém pode ser utilizado copinhos descartáveis para efetuar a prática, uma vez que nem sempre dispomos desse componente. No entanto, seria interessante a utilização de copinhos de vidro transparentes, pois esses permitem a visualização do conteúdo externo, sendo assim mais recomendáveis. 
Research, Society and Development, v. 10, n. 4, e52110414441, 2021

(CC BY 4.0) | ISSN 2525-3409 | DOI: http://dx.doi.org/10.33448/rsd-v10i4.14441

Figura 2. Alimentos a serem testados acondicionados no tubo de ensaio com $2 \mathrm{ml}$ de água. 1: Leite integral, 2: Carne de frango, 3: Whey protein em pó, 4: Colágeno hidrolisado em pó.

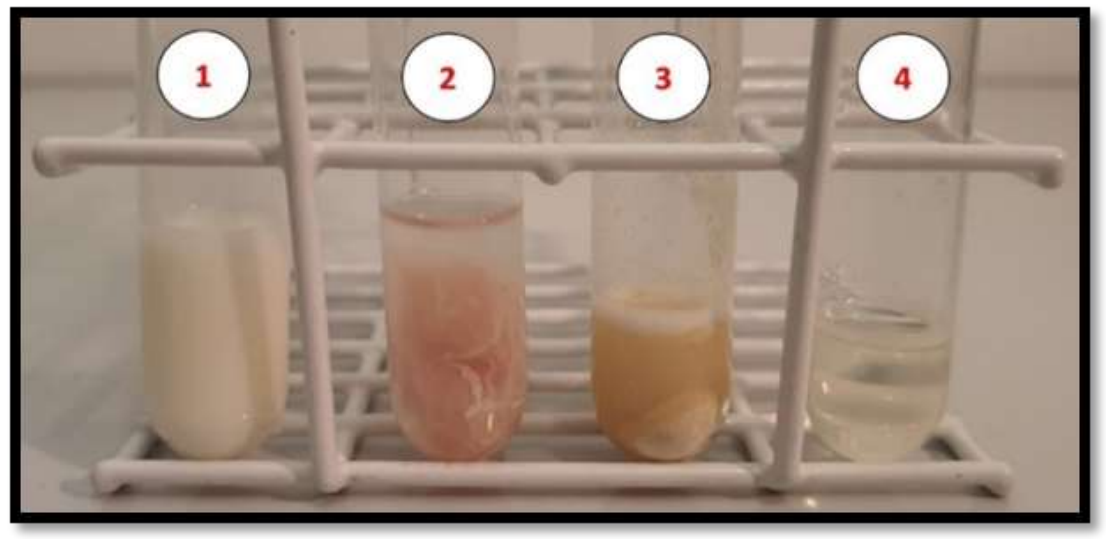

Fonte: Autores (2021).

Figura 3. Alimentos a serem testados acondicionados no tubo de ensaio com $2 \mathrm{ml}$ de água. 5: Extrato de ervilhas em pó, 6: Clara de ovo, 7: Gema de ovo, 8: Castanha-do-pará.

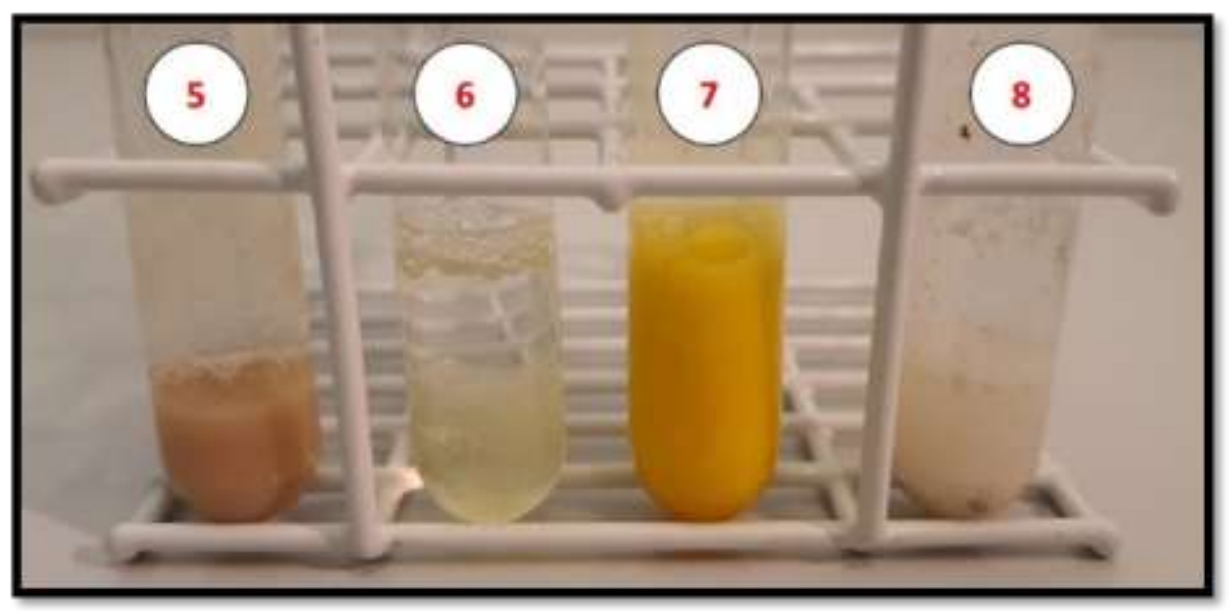

Fonte: Autores (2021).

Figura 4. Alimentos a serem testados acondicionados no tubo de ensaio com $2 \mathrm{ml}$ de água. 9: amido de milho, 10: Pão. 11 Reativo de Biureto.

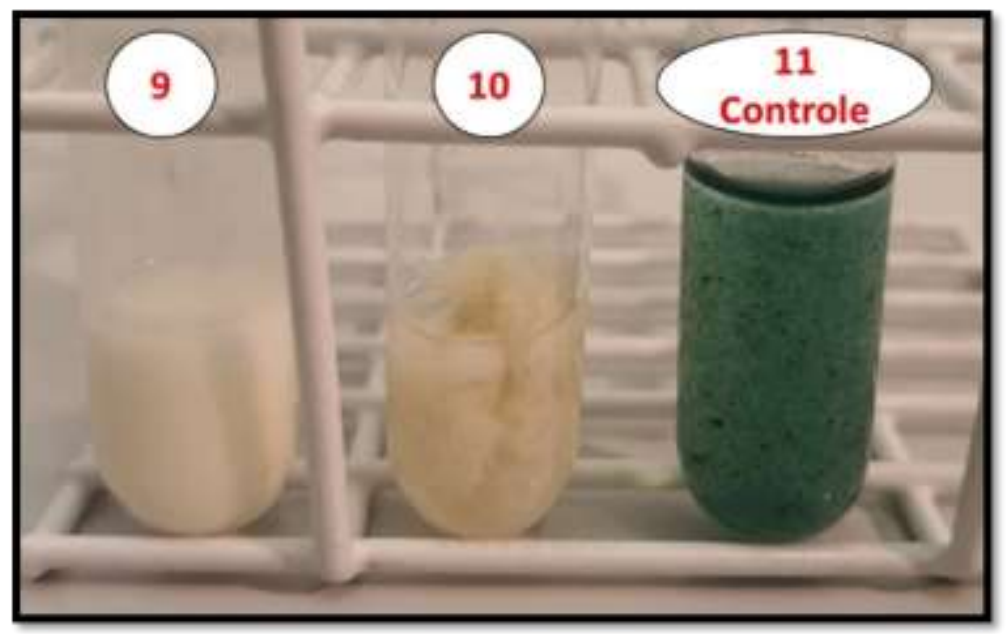

Fonte: Autores (2021). 


\subsection{Adicionando o reagente de biureto em cada um dos copinhos}

Nos copinhos enumerados de 1 a 11, deverá ser colocado com o auxílio de uma seringa graduada, um total de $3 \mathrm{ml}$ do reagente de Biureto. Vale a pena ressaltarmos que o copinho de número 11 irá conter apenas $2 \mathrm{ml}$ de água $+3 \mathrm{ml}$ do Reativo de Biureto pois este será o nosso controle da reação. A partir de agora, as reações químicas começam a acontecer. Observar atentamente a coloração dos copinhos. Ao finalizar essa etapa, pedir aos alunos que registrem os fenômenos ocorridos anotando o que aconteceu em cada um dos copinhos, formulando as hipóteses, relacionando com o que foi aprendido nas aulas teóricas de bioquímica de proteínas.

\section{Resultados Esperados}

No caso de detectarmos uma reação positiva para proteínas com o reagente de Biureto iremos observar a mudança de coloração do meio de azul para a cor roxo, como pode ser observado na Figura 5. Assim, podemos comparar os resultados dos tubos sempre observando o tubo de ensaio número 11 (controle da reação). Nos tubos de ensaio, 1 (Leite Integral), 2 (Carne de frango moída), 3 (Whey protein em pó), 4 (Colágeno hidrolisado em pó), 5 (Extrato de ervilha em pó), 6 (Clara de ovo), 7: (Gema de ovo) e 8 (Castanha-do-pará processada) ocorreram mudança de cor do zul para o roxo, evidenciando a presença de proteínas (Figura 5). Na Figura 6, estão dispostas as amostras negativas para a ocorrência de proteínas. Sendo elas, o amido de milho e o pão. Essas amostras receberam resultado negativo pois não ocorreram mudanças de coloração quando foi adicionado o reativo de Biureto. Dessa maneira, podemos observar que no tubo 9 (amido de milho) e no tubo 10 (Pão) não foram encontradas proteínas (Figura 6).

Figura 5. Identificação de proteínas por meio do teste de Biureto. 1: Leite Integral (+), 2: Carne de frango moída (+), 3: Whey protein em pó (+), 4: Colágeno hidrolisado em pó (+), 5: Extrato de ervilha em pó (+), 6: Clara de ovo (+), 7: Gema de ovo (+) e 8: Castanha-do-pará processada (pó). O sinal (+) indica reação positiva para proteínas.

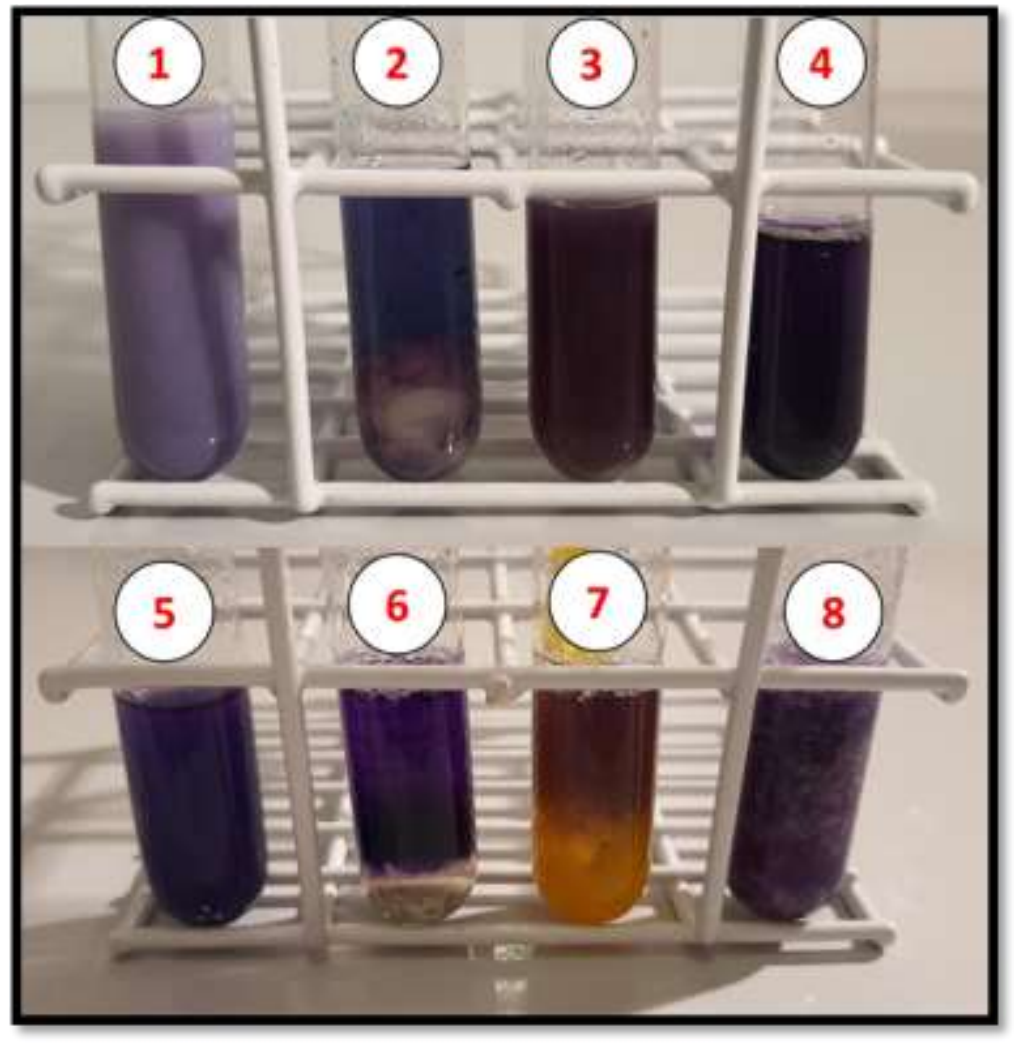

Fonte: Autores (2021). 
Figura 6. Amostras negativas para proteínas. 9: amido de milho, 10: Pão e em 11, é o nosso controle da reação (Reativo de Biureto). O sinal (-) indica ausência de proteínas na amostra. Observar a coloração azul clara.

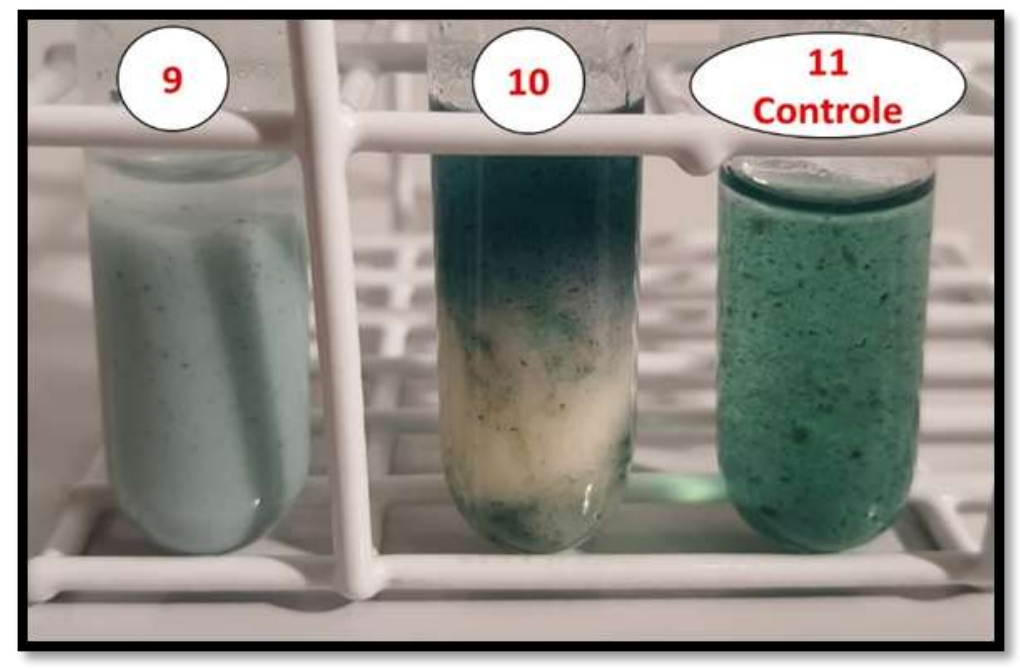

Fonte: Autores (2021).

\section{Abordagens e Discussões dos Resultados da Aula Prática aos Alunos}

No escopo da Bioquímica, o professor pode inicialmente sugerir aos alunos que formulem hipóteses explicando o porquê que nos alimentos enumerados de 1 a 8 ocorreram mudanças de coloração de azul para roxo, e no amido de milho (9) e o pão (10) permaneceram azuis. Após as discussões o professor pode explicar aos alunos que a alteração de cor está relacionada com a existência de proteínas e de ligações peptídicas.

O reagente que é utilizado nessa aula prática para identificar as proteínas é denominado de Reagente ou Reativo de Biureto, esse reagente é constituído por ( $\mathrm{NaOH}+\mathrm{CuSO} 4$ a 5\%). O NaOH é uma base, com pH bastante alto (em torno de 12, 13). Essa base extremamente alcalina irá preparar o meio para que o Sulfato de Cobre (CuSO4) possa reagir dentro das proteínas. Já, o Sulfato de Cobre possui grande afinidade com os aminoácidos das proteínas, permitindo que íon $\mathrm{Cu}^{2+}$ possa se complexar nas ligações peptídicas dos aminoácidos. Na Figura 7, está disposto uma ilustração da interação entre o íon cobre e a estrutura interna da proteína. Essa ligação muda a cor do meio, inicialmente de azul claro para roxo, evidenciando-se assim que alí encontramos proteínas na nossa amostra. Do contrário, alimentos que não possuem proteínas não terão ligações peptídicas, e então o elemento cobre não fará ligações químicas, assim, o meio não mudará de cor, permanecendo azul como visto com o amido de milho, e o pão. Desta forma, os alunos poderão formular hipóteses e explicar os resultados observados.

Nesta etapa da aula, o professor também pode relembrar aos alunos a parte teórica dos níveis estruturais das proteínas, ou seja, a estrutura primária, secundária, terciária e quaternária, enfatizar a existência de ligações peptídicas entre os aminoácidos, e discutir que o calor, e até mesmo a mudança abrupta de pH do meio pode levar ao rompimento dessas ligações, tornando as proteínas desnaturadas, perdendo sua forma e função.

O professor também pode destacar aos alunos o papel imprescindível que as proteínas possuem nos seres vivos. Essas moléculas tão diminutas, desempenham diversas funções desde papéis de defesa como os anticorpos, nos protegendo contra o ataque iminente de bactérias e vírus; estruturais como é o caso do colágeno presente na matriz extracelular, da queratina na pele, da actina e da miosina na contração muscular. Além de assumirem funções enzimáticas como é o caso da DNA polimerase que participa do processo de replicação do DNA, a pepsina que atua na degradação de proteínas no estômago e papéis de transporte como é o caso da hemoglobina em nosso sistema circulatório. 
Figura 7. Representação da interação entre o íon cobre e a estrutura interna da proteína.

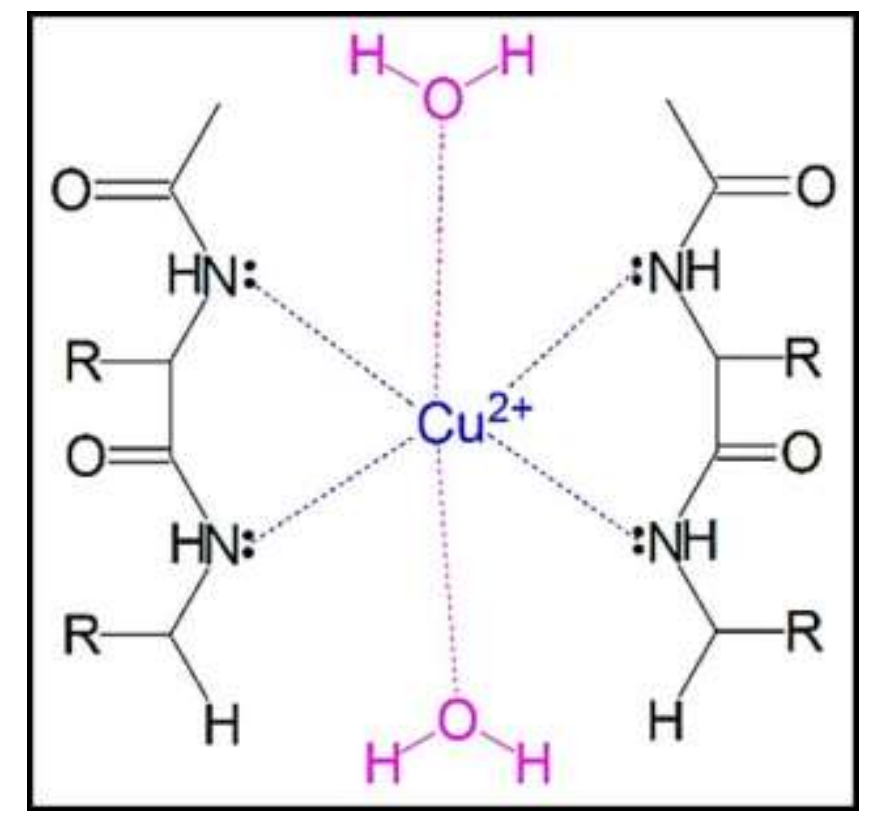

Fonte: Almeida et al. (2012).

Outra abordagem válida, é discussão baseada no papel dos alimentos e compostos utilizados na aula prática para a composição da nossa dieta. Como início dessa discussão, pode ser tomado como exemplo o Whey protein. Na Figura 5, esse composto, exibiu coloração bem intensa, indicando expressiva presença de proteínas. Explicar aos alunos que o Whey protein comercializado, é definido como um composto de proteínas solúveis do leite. Segundo Haraguchi, Abreu e Paula (2006), essas proteínas isoladas constituem-se de frações, ou peptídeos do soro, sendo formadas por: beta-lactoglobulina (BLG), alfalactoalbumina (ALA), albumina do soro bovino (BSA), imunoglobulinas (Ig's) e glico-macropeptídeos (GMP). Assim, os autores ressaltam que o uso desse composto é de grande aplicabilidade no esporte, com possíveis efeitos sobre a síntese proteica muscular esquelética, redução da gordura corporal, bem como na modulação da adiposidade, e melhora do desempenho físico.

Outro alimento que pode ser discutido é o ovo, de extrema relevância na nossa dieta cotidiana. Esse alimento, apresentou reação positiva para o teste do Biureto, assim, tanto a clara quanto a gema exibiram a coloração roxo intenso (Figura 5). Discutir com os alunos a importância do ovo na nossa dieta, enfatizando que é dotado de uma rica fonte de proteínas. Segundo Carolino et al. (2018), o ovo de galinha é considerado um alimento natural de elevado valor nutritivo e de baixo custo. Os ovos são uma importante fonte de proteínas, de baixo teor calórico e de fácil digestibilidade para a dieta humana, pelo que são consumidos pelas várias faixas etárias, e um dos poucos alimentos ingeridos em todo o mundo. Segundo Neves e Henry (2012), a gema do ovo possui proteínas de alto valor biológico, ácidos graxos essenciais, fosfolipídeos e glicerol. Já a clara, possui 88,5\% de água, 13,5\% de proteínas, $11 \%$ de gorduras, hidratos de carbono e a Riboflavina, que é uma vitamina do complexo B, além de possuir as vitaminas A, D, E e K (Fao, 2010; Carolino et al., 2018).

No que tange ao leite, bebida de grande importância na nossa sociedade, o teste de Biureto nos mostrou a presença de proteínas, uma vez que obteve uma coloração roxo claro. Aqui, o professor pode debater com os alunos a importância dessa bebida na nossa dieta. Segundo, Silva (1997), o leite é constituído de água, gorduras, todas as vitaminas conhecidas, entre elas, as vitaminas A, D, E e K, as proteínas enzimáticas como as como lipases, proteinases, óxido-redutases, fosfatases, catalase, peroxidase, além de lactose que é um dissacarídeo formado a partir da glicose e da galactose. Nesta parte da aula o professor pode relembrar os alunos sobre os carboidratos, revisando suas estruturas químicas. 
Outra abordagem interessante é ressaltar as proteínas da castanha-do-pará, e do extrato de ervilha em pó. Ambas, apresentaram resultado positivo para a reação do Biureto, exibindo forte coloração roxa (Figura 5). Segundo, Santos et al. (2006), a castanha-do-pará, é uma semente do fruto da espécie Bertholletia excelsa Humboldt \& Bonpland, sendo popularmente conhecida como castanha-do-pará castanha-do-brasil. Suas castanhas ou sementes são muito apreciadas, sendo reconhecidas internacionalmente, constituindo-se um dos principais produtos de exportação da Amazônia (Santos et al., 2006). Sua semente é rica em proteínas, presentes no endosperma que desempenham um papel determinante na nutrição do embrião da planta. Já na ervilha (Pisum sativum) o professor poderá destacar aos alunos que de acordo com Delgado-Andrade (2016), por ser uma leguminosa, as ervilhas são uma fonte de boa qualidade em carboidratos e proteínas, exibindo um elevado conteúdo em fibras, com baixo teor de lipídios (com excessão da soja e do amendoim), níveis importantes de certos minerais como o cálcio, magnésio, potássio, ferro e zinco, assim como vitaminas especialmente as do complexo B e ácido fólico.

Como sugestão de enriquecimento da atividade, o professor pode fazer uma ligação com o conteúdo de Botânica e Fisiologia Vegetal, ressaltando aspectos da morfologia geral das angiospermas, relembrando aspectos da semente e do fruto.

\section{Lista de Exercícios Proposta}

1. Formule as hipóteses para a mudança de coloração nos copinhos. Porquê na maioria deles ocorreram mudança de coloração do azul para roxo? Enquanto que no pão e no amido de milho essa mudança não ocorreu? Justifique sua resposta.

2. Qual o papel de utilizarmos Hidróxido de Sódio $(\mathrm{NaOH})$ na composição do Reagente de Biureto?

3. Imagine, que na sua amostra, você possui apenas aminoácidos livres. O teste do Biureto irá funcionar nesse caso? Justifique.

4. João, testou dois tubos de ensaio contendo farinha de trigo e extrato de soja. Em quais deles você esperaria ocorrer a mudança de coloração de azul para roxo? Justifique.

\section{Resposta dos Exercícios Propostos}

1. A mudança de coloração dos copinhos é devido a presença de proteínas nas amostras. Assim nas amostras de 1 a 8 , houve mudança de coloração do meio de azul para roxo, pois o Cobre se complexou nas ligações peptídicas das proteínas presentes no alimento, alterando a cor do meio. Já para o amido e o pão (amostras 9 e 10), como não são formados por proteínas e sim amido, não ocorreu mudança de coloração do meio, permanecendo azuis.

2. O Hidróxido de Sódio $(\mathrm{NaOH})$ é uma base forte, e no experimento ele possui a finalidade de preparar o meio para o Sulfato de Cobre agir por meio das ligações entre os aminoácidos das proteínas (ligações peptídicas).

3. Com aminoácidos livres esse teste não irá dar reação, uma vez que é necessário possuir na amostra peptídeos e proteínas, por estes conterem ligações peptídicas entre os aminoácidos. Permitindo assim a complexação do íon cúprico. 
4. Farinha de trigo (-) e extrato de soja em pó (+). A farinha de trigo com o teste do Biureto dará negativo, não alterando a cor do meio, uma vez que nessa amostra não ocorre proteínas e sim amido. Já com o extrato de soja ocorrerá mudança de coloração do azul para o roxo, pois no caso dessa amostra temos a presença de proteínas de origem vegetal.

\section{Conclusões}

Podemos concluir que a abordagem da atividade experimental proposta, pode facilitar o processo norteador do ensino e da aprendizagem, aumentando a motivação do aluno na disciplina de Bioquímica. Além disso, essa atividade permite transpor na prática o que foi aprendido nas aulas teóricas, tornando mais significativa a assimilação do conhecimento.

Como aplicação futura, poderá ser proposto aos alunos outras práticas experimentais aplicadas dentro da Bioquímica, como por exemplo o papel das enzimas nos sistemas biológicos. Nesse sentido, o professor poderá propor uma aula prática utilizando materiais simples e de baixo custo para verificação da atividade proteolítica da bromelina e da papaína, presentes nos sucos de frutas tropicais (abacaxi e mamão, respectivamente), agindo sobre a degradação da gelatina caseira (Gonçalves, 2021a). Assim, a realização de atividades práticas se desponta como muito positivas, permitindo potencializar a experimentação e a ótica científica dos discentes.

\section{Referências}

Almeida, V. V., Canesin, E. A., Suzuki, R. M., \& Palioto, G. F. (2013). Análise Qualitativa de Proteínas em Alimentos Por Meio de Reação de Complexação do Íon Cúprico. Química Nova na Escola, 35(1), 34-40. http://qnesc.sbq.org.br/online/qnesc35_1/06-EEQ-79-11.pdf

Azevedo, M. C. P. S. (2004). Ensino por investigação: problematizando as atividades em sala de aula. In Carvalho, A. M. P. C. (Org.). Ensino de Ciências: unindo a pesquisa e a prática. (pp. 19-33). Cengage Learning.

Carolino, I., Cid, J., Lordelo, M., Ribeiro, V., Alves, S., Bessa, R.; \& Carolino. N. (2018) Composição química dos ovos de galinhas de raças autóctones. https://vozdocampo.pt/2018/03/12/composicao-quimica-dos-ovos-de-galinhas-de-racas-autoctones/

Costa, K, S., \& Farias, G. G. (2008). EAD: sua origem histórica, evolução e atualidade brasileira em face ao paradigma da educação presencial. http://www.abed.org.br/congresso2008/tc/552008104927AM.pdf

Delgado-Andrade, C., Olías, R., Jiménez-López, J, C., \& Clemente, A. (2016). Aspectos de las legumbres nutricionales y beneficiosos para la salud humana. ARBOR Ciencia, Pensamiento y Cultura. http://arbor.revistas.csic.es/index.php/arbor/article/view/2117/2774

Fao. (2010). Food and Agriculture Organization. Agribusiness Handbook - Poultry Meat \& eggs. http://www.fao.org/docrep/012/al175e/al175e.pdf

Gonçalves, T. M. (2021a). Ensinando Biologia em tempos de pandemia: um laboratório caseiro com materiais simples e de baixo custo para a simulação da digestão de proteínas. Revista Educação Pública, 21(5), 1-6. https://educacaopublica.cecierj.edu.br/artigos/21/5/ensinando-biologia-em-tempos-de-pandemiaum-laboratorio-caseiro-com-materiais-simples-e-de-baixo-custo-para-a-simulacao-da-digestao-de-proteinas

Gonçalves, T. M. (2021b). Permeabilidade da membrana plasmática celular da beterraba: uma proposta de aula prática no ensino médio. Research, Society and Development. 10(3). 1-9. https://rsdjournal.org/index.php/rsd/article/view/13479

Haraguchi, F. K., Abreu, W. C., \& De Paula, H. (2006). Proteínas do soro do leite: composição, propriedades nutricionais, aplicações no esporte e benefícios para a saúde humana Whey protein: composition, nutritional properties, appications in sports and benefits for human health. Revista de Nutrição Campinas, $19(4), 479-488$

Inep. (2019). Instituto Nacional de Estudos e Pesquisas Educacionais Anísio Teixeira. Notas estatísticas 2019. https://download.inep.gov.br/educacao_superior/censo_superior/documentos/2020/Notas_Estatisticas_Censo_da_Educacao_Superior_2019.pdf

Interaminense, B. K.S. (2019). A Importância das aulas práticas no ensino da Biologia: Uma Metodologia Interativa. Id Online Revista Multidisciplinar e de Psicologia, 13(45), 342-354. https://idonline.emnuvens.com.br/id/article/view/1842/2675

Lacerda, F. K. D., \& Espíndola, R. M. (2013). Evasão na educação a distância: um estudo de caso. Revista Ead em foco, 3(1), 96-108.

Marques, C. (2004). Ensino a distância começou com cartas e agricultores. Folha Online. http://www1.folha.uol.com.br/folha/educacao/ult305u396511.shtml

Neder, M. L. C. Educação a distância e sua contribuição na mudança de paradigmas educacionais na formação de professores. In: Desafios da educação a distância na formação de professores. Brasília: MEC/Secretaria de Educação a Distância, 2006. p. 79-85.

Nelson, D. L., \& Cox, M. M. Princípios da Bioquímica de Lehninger, (4a ed.), Sarvier.

Neves, M. M., \& Henry, M. (2012). Gema de ovo de galinha e a ação protetora de suas lipoproteínas de baixa densidade na criopreservação do sêmen. Revista Brasileira de Reprodução Animal, 36(4), 209-214. 
Research, Society and Development, v. 10, n. 4, e52110414441, 2021

(CC BY 4.0) | ISSN 2525-3409 | DOI: http://dx.doi.org/10.33448/rsd-v10i4.14441

Pereira, A.S., Shitsuka, D. M., Parreira, F. J., \& Shitsuka, R. (2018). Metodologia da pesquisa científica. UFSM. https://www.ufsm.br/app/uploads/sites/358/ 2019/02/Met odologia-da-Pesquisa-Cientifica_final.pdf

Santos, J. U. M., Bastos, M. N. C., Gurgel, E. S. C., \& Carvalho, A. C. M. (2006). Bertholletia excelsa Humboldt \& Bonpland (Lecythidaceae): aspectos morfológicos do fruto, da semente e da plântula. Boletim do Museu Paraense Emílio Goeldi. Ciências Naturais. 1(2), 103-112. http://scielo.iec.gov.br/pdf/bmpegcn/v1n2/v1n2a07.pdf

Silva, P. H. F. (1997). Leite: Aspectos de Composição e Propriedade. Química Nova na Escola, 6, 3-5.

Trivelato, S. F., Silva, R. L. F. Ensino de Ciências, Cengage Learning.

Voet, D., Voet, J. G., \& Pratt, C. W. Fundamentos de bioquímica: A vida em nível molecular, (2a ed.), Artmed. 